\title{
The continuous thermal imaging of the flood embankment to identify location of the leaks
}

\author{
by B. Bukowska-Belniak*, A. Borecka*, A. Leśniak*
}

*AGH University of Science and Technology, al. Mickiewicza 30, 30-059 Krakow, Poland, bukowska@agh.edu.pl, aborecka@agh.edu.pl, lesniak@agh.edu.pl

\section{Abstract}

The interpretation of continuous thermographic measurements of leaking soil embankment is presented in the abstract. The measurements were conducted at the daybreak and sunny morning, when air temperature rose intensively. The temperature of leak regions has increased slowly in contrary to temperature of dry one regions. Examining differential thermal images taken with one-hour delay, it was possible to detect the horizontal zone where the sand layer was located and water filtration on embankment surface existed.

\section{Introduction}

Leaks in flood embankments in their weakened parts are one of the reasons of their failure / break and the occurrence of flood. As part of the ISMOP project [1], an artificial, real size flood embankment was built, and investigations of the embankment body behavior were carried out when high water level was kept. Several flood experiments have been conducted. The experimental embankment was equipped with optical fiber as well as with a distributed sensor system inside the shaft, and two weather stations [2,3]. Additionally, other external measurements were carried out, like: surveying, geoelectrical sounding and profiling, thermographical and hyperspectral monitoring. The data were recorded under dry and flood conditions continuously for almost 2 years. Also the numerical models of water filtration in experimental embankment were made [4].

Some preliminary measurements, including infrared imaging, were made on small experimental embankment (built in scale 1:5, without grass on its surface) before the large experimental embankment was built. Analyzes of the filtration process, numerical models and infrared imaging proved that infrared monitoring is useful in detecting the water leakages in such soil embankment $[5,6]$.

\section{Thermographical measurements}

The thermographical measurements were carried out during several experiments that were conducted in different seasons and lasts for several days. In November 2016 experiment, during the occurrence of a leak in the NW part of the embankment the stationary thermal image recording was performed with a 5-minute step. Figure 1 presents six images taken by FLIR T620 microbolometer camera. There are no visible places of leaks on the surface of the embankment, despite their occurrence in this area.

$5: 50$

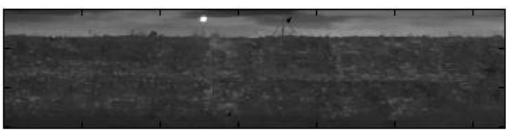

$8: 50$

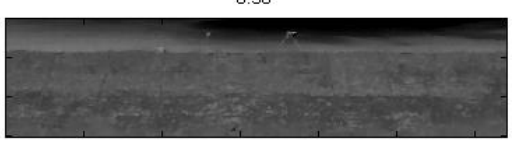

$6: 50$

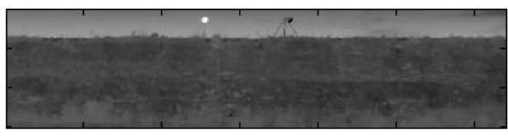

9:50

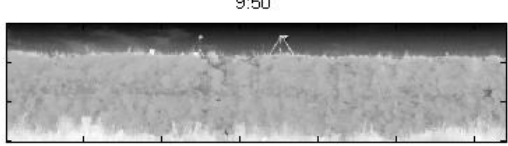

$7: 50$

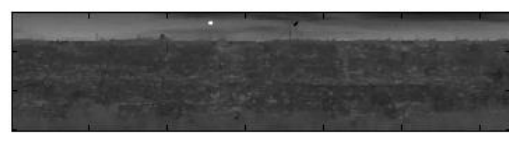

10:50

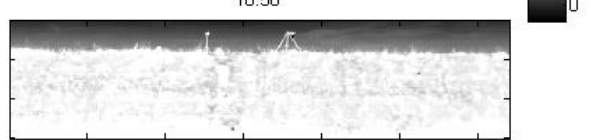

Fig. 1: Thermal images taken in daybreak and morning at 5:50, 6:50, 7:50, 8:50, 9:50 and 10:50 [ ${ }^{\circ} \mathrm{C}$.

As it was shown in figure 2 there was a rapid rise $\left(12^{\circ} \mathrm{C}\right)$ in air temperature between 7:00 and 10:00 in that day. The sun rose at 7:00. After 8:00 the temperature of the embankment began to increase. 


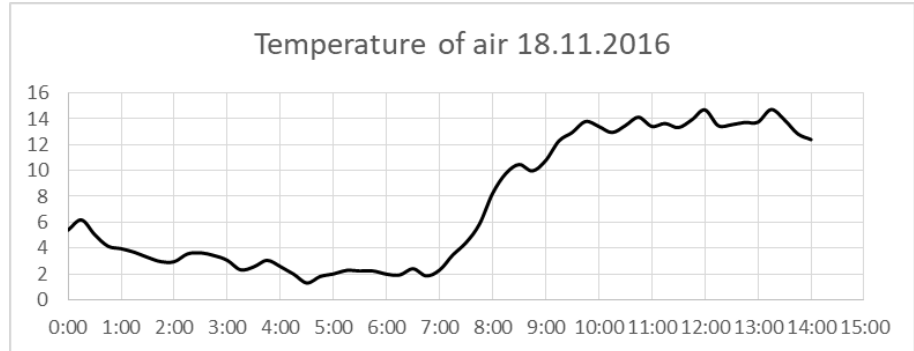

Fig. 2: Temperature of air measured by weather station in ${ }^{\circ} \mathrm{C}$.

There is expected that when air temperature raises in damp areas of the embankment the temperature increases more slowly than in adjacent, dry areas. After performing the subtraction of the consecutive thermal images, the leak regions became visible as can be seen in Figure 3. A strip shape dark area, $1.6 \mathrm{~m}$ above embankment base is visible, where more permeable layer of sands exists (fig.3 9:50-8:50).

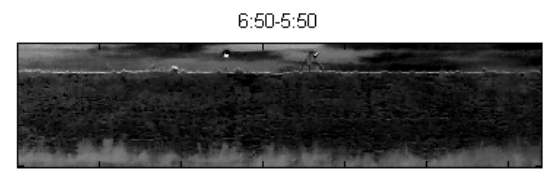

9:50-8:50

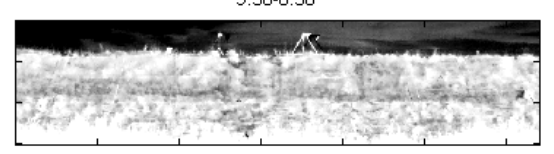

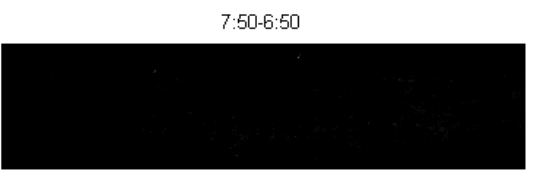

$10: 50-9: 50$

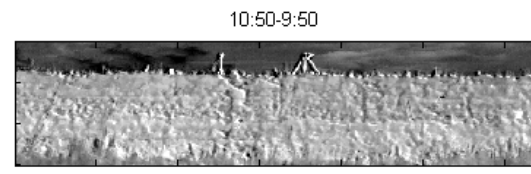

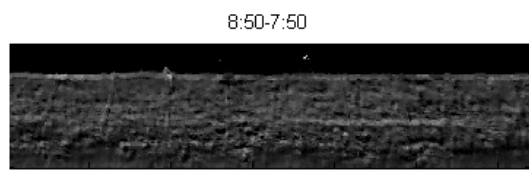

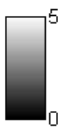

Fig. 3: Differences in temperature in each hour of measurement - subtraction images $\left[{ }^{\circ} \mathrm{C}\right]$.

\section{Conclusions}

Leaks occurring in levees are difficult to locate using direct thermographic measurement. The water filtration process through the stable embankment is slow and temperatures of the soil and the filtering water are similar. The occurring vegetation makes the results of the temperature measurement more difficult for interpretation. Leaks can be located when the embankment is exposed to an external thermal impulse, which is the Sun. As a result of such an embankment heating, it wet parts heats up more slowly than dry, which gives the possibility of locating the leak by examination of differential infrared images.

\section{Acknowledgements}

This work was partly supported by the National Centre of Research and Development (NCBiR), Poland, project PBS1/B9/18/2013 (no.180535) [1]; and by the AGH University of Science and Technology, Faculty of Geology, Geophysics and Environmental Protection as a part of statutory research project no. 11.11.140.613.

\section{REFERENCES}

[1] ISMOP - Computer System for Monitoring River Embankments (in Polish: Informatyczny System Monitorowania Obwalowań Przeciwpowodziowych), www.ismop.edu.pl.

[2] Sekuła K., Borecka A., Kessler D., Majerski P., Smart levee in Poland. Full-scale monitoring experimental study of levees by different methods. Computer Science. 2017;18(4). DOI: http://dx.doi.org/10.7494/csci.2017.18.4.2220

[3] Baliś B., Bartyński T., Brzoza-Woch R., et al., Dedicated IT infrastructure for Smart Levee Monitoring and flood Decision. E3S Web Conf. Volume 7, 2016. $3^{\text {rd }}$ European Conference on Flood Risk Management (FLOODrisk 2016). DOI: $10.1051 / \mathrm{e} 3$ sconf/20160714008.

[4] Dwornik M., Krawiec K., Franczyk A., Leśniak A., 2016. Numerical modelling of levee stability based on coupled mechanical thermal and hydrogeological processes. E3S Web Conf. Volume 7, 2016. $3^{\text {rd }}$ European Conference on Flood Risk Management (FLOODrisk 2016). DOI: 10.1051/e3sconf/20160703021.

[5] Bukowska-Belniak B., Leśniak A., Image processing of leaks detection in sequence of infrared images Measurement, Automation, Monitoring. 2017;63(4):131-134.

[6] Krawiec K., Bukowska-Belniak B., Leśniak A., Kessler D., Analysis of the filtration processes in soil embankment based on numerical modelling and temperature measurements. E3S Web Conf. Volume 7, 2016. $3^{\text {rd }}$ European Conference on Flood Risk Management (FLOODrisk 2016). DOI:10.1051/e3sconf/20160703018. 